\title{
Phenotypic and genotypic characterization of Staphylococcus aureus isolated from
}

\section{pork sausage}

\author{
Caracterização fenotípica e genotípica de Staphylococcus aureus isolados de linguiça suína \\ Caracterización fenotípica y genotípica de Staphylococcus aureus aislado de salchicha porcina
}

Received: 02/16/2021 | Reviewed: 02/19/2021 |Accept: 02/23/2021 | Published: 01/03/2021

\author{
Kauana Kaefer \\ ORCID: https://orcid.org/0000-0003-1968-3684 \\ Universidade Federal do Rio Grande do Sul, Brasil \\ E-mail: kauanakaefer@gmail.com \\ Débora Rodrigues Silveira \\ ORCID: https://orcid.org/0000-0002-7245-279X \\ Universidade Federal de Pelotas, Brasil \\ E-mail: debora.rsilveira@ hotmail.com \\ Juliana Fernandes Rosa \\ ORCID: https://orcid.org/0000-0002-5169-4933 \\ Universidade Federal de Pelotas, Brasil \\ E-mail: juliana_fernandes.r@hotmail.com \\ Thaís Gonçalves Gonçalves \\ ORCID: https://orcid.org/0000-0003-3626-2435 \\ Universidade Federal de Pelotas, Brasil \\ E-mail: thaais.g@hotmail.com \\ Thamíris Pereira de Moraes \\ ORCID: https://orcid.org/0000-0002-1513-930X \\ Universidade Federal de Pelotas, Brasil \\ E-mail: thamiris.p@outlook.com \\ Cláudio Dias Timm \\ ORCID: https://orcid.org/0000-0003-3920-9066 \\ Universidade Federal de Pelotas, Brasil \\ E-mail: claudiotimm@hotmail.com
}

\begin{abstract}
The objective of this study was to characterize the genotype and phenotype of $S$. aureus isolates from pork sausages. Fifty samples of pork sausages were collected, counts of coagulase-positive Staphylococcus were made and isolates were obtained to identify $S$. aureus species. In the isolates, the presence of genes sea, seb, sec, and sed was surveyed, the methicillin-resistance was assessed and the production of biofilm in Congo red agar, stainless steel, polyethylene, glass, and pork casing was tested. The capacity of biofilm formation was assessed after the exposure to sublethal stress. Of the samples tested, $12 \%$ had counts superior to what is permitted by the legislation. S. aureus was isolated in $44 \%$ of the samples. Of these, $54 \%$ had only the gene sed and $32 \%$ had genes sec and sed, $73 \%$ were classified as methicillin-resistant S. aureus (MRSA). Of the MRSA isolates, $62 \%$ had only gene sed and 35\% had both genes found in this study. Regarding the biofilm formation in Congo red agar, $68 \%$ of $S$. aureus isolates were considered as biofilm formers. After undergoing the sublethal stress, most of the biofilm former isolates proceeded to form biofilm and the non-biofilm former isolates responded in a distinct manner. The condition in which the sublethal stress greatly induced the biofilm formation was the cold. Biofilm production was observed only in the stainless steel and pork casing in $71 \%$ and $57 \%$ of the isolates tested, respectively. Thus, we stress the importance of implementing good manufacturing practices within the industry to control microbial contamination and biofilm formation.
\end{abstract}

Keywords: Biofilm; Enterotoxins; Methicillin; Public health; Sublethal stress.

\section{Resumo}

O objetivo desse estudo foi caracterizar o genótipo e fenótipo de $S$. aureus isolados de linguiça suína. Cinquenta amostras de linguiça suína foram coletadas, foram realizadas contagens de Staphyloccus coagulase positiva e obtidos isolados para identificar a espécie $S$. aureus. Nos isolados, foi pesquisada a presença dos genes sea, seb, sec e sed, feita a avaliação da resistência a meticilina e testada a produção de biofilme em Ágar Vermelho Congo, aço inoxidável, polietileno, vidro e tripa suína. Também foi verificada a capacidade de alguns isolados formarem biofilme após a exposição a estresses subletais. Das amostras testadas, $12 \%$ apresentaram contagens acima do permitido pela legislação. S. aureus foi isolado de $44 \%$ das amostras. Destes, $54 \%$ possuíam apenas o gene sed e $32 \%$ possuíam os genes sec e sed, $73 \%$ foram classificados como S. aureus resistentes à meticilina (MRSA). Dos MRSA 62\% possuíam apenas o gene sed e 35\% possuíam ambos os genes encontrados no estudo. Quanto a formação de biofilme em ágar vermelho congo, $68 \%$ dos isolados de $\mathrm{S}$. aureus foram considerados formadores de biofilme. Após serem submetidos 
aos estresses subletais, a maioria dos isolados formadores de biofilme continuou formando biofilme e os isolados não formadores de biofilme responderam de maneira distinta. A condição de estresse subletal que mais induziu a formação de biofilme foi o frio. A produção de biofilme foi observada apenas no aço inoxidável e na tripa suína em $71 \%$ e $57 \%$ dos isolados testados, respectivamente. Assim, ressalta-se a importância da implementação de boas práticas dentro da indústria para controlar a contaminação microbiana e a formação de biofilme.

Palavras-chave: Biofilme; Enterotoxinas; Meticilina; Saúde pública; Estresse subletal.

\section{Resumen}

El objetivo de este estudio fue caracterizar el genotipo y fenotipo de $S$. aureus aislado de salchicha porcina. Se recolectaron 50 muestras de salchicha porcina, se realizaron recuentos positivos de Staphyloccus coagulasa positivo y se obtuvieron aislamientos para identificar la especie $S$. aureus. En los aislamientos se investigó la presencia de los genes sea, seb, sec y sed, se evaluó la resistencia a la meticilina y se probó la producción de biopelículas en Agar Rojo Congo, acero inoxidable, polietileno, vidrio y tripa porcina. También se verificó la capacidad de algunos aislamientos para formar biopelículas después de la exposición a tensiones subletales. De las muestras analizadas, el 12\% tenía recuentos superiores a los permitidos por la legislación. Se aisló S. aureus del 44\% de las muestras. De estos, el 54\% tenía solo el gen sed y el $32 \%$ tenía los genes sec y sed, el $73 \%$ se clasificó como $S$. aureus resistente a la meticilina (MRSA). Del MRSA, el 62\% tenía solo el gen sed y el 35\% tenía ambos genes encontrados en el estudio. En cuanto a la formación de biopelículas en agar rojo Congo, el 68\% de los aislados de $S$. aureus se consideraron formadores de biopelículas. Después de someterse a tensiones subletales, la mayoría de los aislados formadores de biopelículas continuaron formando biopelículas y los aislados que no eran formadores biopelículas respondieron de manera diferente. La condición de estrés subletal que más indujo la formación de biopelículas fue el frío. La producción de biopelículas se observó solo en acero inoxidable y tripa porcina en el $71 \%$ y el $57 \%$ de los aislamientos probados, respectivamente. Por lo tanto, enfatiza la importancia de implementar buenas prácticas dentro de la industria para controlar la contaminación microbiana y la formación de biopelículas.

Palabras clave: Biopelícula; Enterotoxinas; Meticilina; Salud pública; Estrés subletal.

\section{Introduction}

Pork is the most consumed meat worldwide (USDA, 2019). Among the industrialized products made from pork, pork sausage stands out for being generated through a simple processing and for having a reasonable price. Sausage is a meat product obtained from ground meat of different domestic animals, with condiments, added or not with other ingredients, stuffed in natural or artificial casing and submitted to specific technological processes (Brasil, 2017).

During the production of fresh sausage, the meat is grounded, which increases the surface exposure to the contamination and microorganism growth and, since it is a fresh product, it does not undergo thermal treatment that eliminates or reduces this contamination. Furthermore, the manufacturing process requires a series of manipulation stages, increasing the possibility of contamination, which would compromise the hygienic-sanitary quality of the final product in case of failures and nonconformity in the processing (Tutenel, et al., 2003). Among the bacteria that could be present in the final product, Staphylococcus aureus stands out. It can be found in the nasal cavities and skin of healthy individuals and also in hogs (Robert \& Chambers, 2005, Linhares, et al. 2015, Strube, et al., 2018).

S. aureus is considered the most relevant species within Staphylococcus genus and is frequently associated with outbreaks of food poisoning due to the great capacity of producing enterotoxins that, once ingested in sufficient amounts, provoke nausea, vomits, cramps, and diarrhea (Lee, et al., 2018; Germano \& Germano, 2015). Staphylococcal enterotoxins (SE) are thermoresistant, therefore, once they are produced in the food, they are not eliminated during thermal processing (Franco \& Landgraf, 2008).

Moreover, S. aureus stands out for being able to develop resistance to different antimicrobials in a fast and effective manner. In this context, methicillin-resistant S. aureus (MRSA) are highly relevant for being resistant to all beta-lactam antibiotics that are commonly used in the treatment of infections caused by this microorganism (De Buyser, et al., 2001, Lowy, 1998). Food contamination caused by MRSA poses a risk of transmission of this microorganism to people that manipulate these foods. In addition, it could occur the methicillin resistance transfer from MRSA to methicillin-sensitive $S$. aureus strains (MSSA). Another concerning factor is that some $S$. aureus strains have the capacity to form biofilms on the surfaces of various 
equipment in food industries, such as stainless steel, plastic, and glass, which could turn them into a persistent source of microbial contamination that could lead to food deterioration and threat the safety of the products to the consumers (Giaouris, et al., 2014). Biofilms are communitarian structures of bacteria covered by a polymeric matrix produced by the bacteria and constituted of polysaccharides, proteins, and nucleic acids, named together as exopolysaccharides (EPS), with the capacity of adhesion to biotic or abiotic surfaces (Haaber, et al., 2012).

During food processing, the microorganisms are submitted to stress conditions such as high temperatures, cooling and acid $\mathrm{pH}$ that could favor the formation of biofilm, since the association of microorganisms in biofilms constitutes a form of protection to its development, permitting their survival in hostile environments (Donlan \& Costerton, 2002).

The objective of the present study was to assess the presence of genes that encode staphylococcal enterotoxins in $S$. aureus isolates from pork sausage and to assess phenotypical traits of the isolates, such as methicillin-resistance and the capacity of biofilm formation in distinct surfaces and under distinct environmental conditions.

\section{Methodology}

During the time of our study, 50 samples of pork sausage were collected from butcher shops and grocery stores in the municipality of Pelotas, Rio Grande do Sul, Brazil, making a total of 19 commercial properties, collecting up to three samples in each local. Samples were stored in isothermal boxes with ice and immediately dispatched to the laboratory to carry out the analysis.

At first, we executed the count of coagulase-positive Staphylococcus (CoPS) collected in Baird-Parker agar (Himedia, Mumbai, India) obtained from sausage samples, according to Tallent et al. (2016). Afterwards, one coagulase-positive isolate of each sample was inoculated in Brain and Heart Infusion (BHI; Himedia, India) broth and incubated at $37^{\circ} \mathrm{C}$ for $24 \mathrm{~h}$. To the BHI culture isolates, $20 \%$ of glycerol was added to maintain a stock culture at $-70^{\circ} \mathrm{C}$ and to identify $S$. aureus by PCR.

The confirmation of $S$. aureus was performed through PCR assay, by surveying the gene nuc. The DNA extraction of coagulase-positive isolates was executed according to Sambrook \& Russel (2001). For the PCR assay, we used the protocol as reported by Sasaki et al. (2010), with modifications. In each $25 \mu \mathrm{L}$ of reaction mixture comprised $1 \mu \mathrm{L}$ DNA extracted, $2 \mathrm{U}$ of Taq DNA polymerase, $10 \mathrm{pmol}$ of each primer, $0.2 \mathrm{nM}$ of deoxyribonucleotide triphosphate (dNTP) and buffer reaction. Amplification was made at $95^{\circ} \mathrm{C}$ for $2 \mathrm{~min}$, followed by 30 cycles of $30^{\circ} \mathrm{C}$ for $30 \mathrm{~s}, 56^{\circ} \mathrm{C}$ for $30 \mathrm{~s}$, and $72^{\circ} \mathrm{C}$ for $1 \mathrm{~min}$, and final elongation at $72^{\circ} \mathrm{C}$ for $2 \mathrm{~min}$. PCR products were stained with Diamond Nucleic Acid Dye (Promega, USA) for visualization in standard gel electrophoresis in a 1.5\% agarose gel (Panreac Química SA, Spain).

The isolates that were identified as $S$. aureus by PCR were submitted to another round of PCR assay to identify the genes that encoded the staphylococcal enterotoxins A (gene sea), B (gene seb), C (gene sec), and D (gene sed), separately. The protocol used was as described by Cunha et al. (2007) with modifications, to survey genes encoding the staphylococcal enterotoxins from A to C. Twenty pmol of each primer, $2.5 \mathrm{U}$ of Taq DNA polymerase, $200 \mu \mathrm{M}$ of dNTPs, 20mM of Tris-HCl, $\mathrm{pH} 8.4,0.75 \mathrm{mM}$ of $\mathrm{MgCl} 2$ and $5 \mu \mathrm{L}$ of DNA were added into a microtube. Amplification consisted of one cycle of $94{ }^{\circ} \mathrm{C}$ for $4 \mathrm{~min}$, denaturation at $94^{\circ} \mathrm{C}$ for $2 \mathrm{~min}$, annealing at $55^{\circ} \mathrm{C}$ for $1.5 \mathrm{~min}$ and extension from oligonucleotide primers at $72{ }^{\circ} \mathrm{C}$ for $1.5 \mathrm{~min}$, followed by a second cycle of denaturation at $94^{\circ} \mathrm{C}$ for $2 \mathrm{~min}$, annealing at $53^{\circ} \mathrm{C}$ for $1.5 \mathrm{~min}$ and extension at $72^{\circ} \mathrm{C}$ for $1.5 \mathrm{~min}$. In the third cycle, the annealing temperature was reduced to $51^{\circ} \mathrm{C}$, followed by additional 37 cycles at $94^{\circ} \mathrm{C}$ for $2 \mathrm{~min}$, $42.5^{\circ} \mathrm{C}$ for $1.5 \mathrm{~min}$ and $72^{\circ} \mathrm{C}$ for $1.5 \mathrm{~min}$. PCR products were visualized as described previously. The survey of gene coding staphylococcal enterotoxin D in the isolates was carried out as described by Andretta (2019).

Disk diffusion test was performed to assess methicillin resistance in Müeller-Hinton agar (Kasvi, Brasil), according to Bauer et al. (1966), in which two disks impregnated with $30 \mu \mathrm{g}$ the antibiotic cefoxitin (CFO). The results were analyzed according to the Clinical and Laboratory Standards Institute (CLSI) (2015), that considers that a microorganism is resistant to 
cefoxitin when the halo formed has a diameter inferior than or equal to $21 \mathrm{~mm}$ and sensitive when the halos had a diameter higher than or equal to $22 \mathrm{~mm}$.

Biofilm production by S. aureus strains was determined by Congo Red agar (CRA, Êxodo Científica, Brazil) culture, as described by Freeman et al. (1989). The production of rough and black colonies was considered as a positive result of biofilm formation and the production of smooth and red colonies as a negative result.

The effect of sublethal stress over the biofilm formation in CRA was assessed. The isolates were submitted to different types of sublethal stress. The cultures were left overnight in BHI maintained in water-bath at $42^{\circ} \mathrm{C}$ for $45 \mathrm{~min}$ to expose cells to heat shock, according to Chang et al. (2004). Cells were also exposed to cold shock and the cultures were left overnight in BHI and maintained at $4^{\circ} \mathrm{C}$ for $4 \mathrm{~h}$ (Silva, 2019). The exposure to acid environment was performed according to Wong et al. (1998). Cultures in BHI left overnight had the $\mathrm{pH}$ adjusted to 5.0 with $\mathrm{HCl} 6 \mathrm{~N}$ and were incubated at $37^{\circ} \mathrm{C}$ for $30 \mathrm{~min}$.

The isolates that were considered as biofilm formers in CRA, classified as MRSA, and/or that had at least one gene that coded any staphylococcal enterotoxin, among the surveyed, were tested for the capacity of biofilm formation in different surfaces, as described by Milan et al. (2015), with modifications. Coupons with flat surfaces of $4 \mathrm{~cm}^{2}$ of high density polyethylene, stainless steel and sterilized glass in autoclave were used. The coupons were deposited on Petri dishes (150 X $20 \mathrm{~mm}$ ) containing $100 \mathrm{~mL}$ of Tryptone soya broth (TSB, Acumedia, USA) and $2 \mathrm{~mL}$ of overnight cultures of each isolate standardized in spectrophotometer at $600 \mathrm{~nm}$ for 0.5 of optical density. Every $24 \mathrm{~h}$ of incubation at $37 \mathrm{oC}$, coupons were gently rinsed twice with phosphate buffer saline (PBS, 0.1 M, pH 7.0) to remove cells that could not adhere and then returned to the Petri dishes with $100 \mathrm{~mL}$ of TSB, but without inoculum, and re-incubated. After three repetitions, the coupon surfaces were rubbed with sterile swabs that were stored in test-tubes containing $10 \mathrm{~mL}$ of PBS. Then, serial dilutions were performed to count microorganisms that grew in Baird-Parker agar. One of the isolates in CRA non-biofilm former was used as negative control.

The isolates that were considered as biofilm-former in CRA and classified as MRSA and/or had at least one gene coding staphylococcal enterotoxin were tested for their ability to form biofilm in pork casing. Strips of dehydrated pork casing, sterilized by plunging in alcohol for $30 \mathrm{~min}$ and dried in drying oven at $60^{\circ} \mathrm{C}$ were used. The rest of the assay was conducted as described aforementioned. Count was performed by rubbing the swab on a $4 \mathrm{~cm}^{2}$ area, delimited by a sterile sampling template.

The assays of biofilm formation in different surfaces were performed in triplicates and the means of S. aureus counts were assessed by analysis of variance and compared by Tukey's test.

\section{Results and Discussion}

Of the 50 samples of fresh pork sausage analyzed, 48\% (24/50) exhibited CoPS, whereas 12\% (6/50) had counts of CoPS above the standard as established by the Resolution of the Collegiate Board (RDC) n. 12/01 (BRASIL, 2001), that admits CoPS counts up to $5.0 \times 10^{3} \mathrm{CFU} / \mathrm{g}$ for sausages. The maximum count found in this study was $6.4 \times 10^{4} \mathrm{CFU} / \mathrm{g}$. A result inferior than what we found in our study was reported by Valiatti et al. (2016), that assessed fresh sausage samples from grocery stores at the municipality of Ji-Paraná, Rondônia, and found that 6.6\% (2/30) exhibited CoPS count above the limit determined by the Brazilian legislation. However, a higher prevalence was reported by Santa et al. (2012), that assessed 50 samples of pork sausage and mixed-meat sausage collected from industries in Southern Brazil and, of these, 15 (30\%) presented CoPS, with 11 (22\%) samples with counts above the limit established by the legislation. On the other hand, Botelho (2017) reports that of the nine samples of pork sausages collected in an abattoir in Viçosa, Minas Gerais, all of them presented CoPS, which could be attributed to extensive manipulation during the prepare of the product; however, none of them had counts higher than the limit stablished. The high counts of CoPS found in our study could be attributed to: (1) inappropriate 
hygienic-sanitary conditions during the manipulation to prepare the sausages, (2) previous contamination of feedstock used in the process, and/or (3) storage under inadequate temperature.

S. aureus was isolated from $44 \%$ (22/50) of the samples. In $92 \%$ (22/24) of the samples in which CoPS growth was observed in the plates, we identified $S$. aureus and this microorganism was present in all samples where counts were superior to the permitted by the legislation.

Since S. aureus is a natural inhabitant of human skin and upper respiratory tract, the presence of this microorganism in the sausage samples surveyed could be attributed to the non-adoption of hygienic-sanitary measures by manipulators. Moreover, some studies report the presence of S. aureus in the skin, tonsils, and rectum of pigs (Linhares, et al., 2015, Strube, et al., 2018), indicating that these animals may host this bacterium and, if proper care are not adopted during the slaughter and the meat processing, this microorganism can contaminate the meat and other carcasses and equipment and utensils due to cross contamination. This could also be a possible cause of the presence of S. aureus in the samples analyzed.

Of the S. aureus isolates, $73 \%$ (16/22) were resistant to cefoxitin, being classified as MRSA, which means that 32\% $(16 / 50)$ of sausage samples was contaminated with microorganisms that were resistant to this antimicrobial. Few studies have reported the presence of MRSA in pork sausages. In a study conducted by Botelho (2017), methicillin resistance was observed in $61.5 \%$ (8/13) of $S$. aureus isolates of seven pork sausage samples, which apparently (the author does not elucidate whether all isolates, even those obtained within the same samples, were distinct strains) was similar in our study. On the other hand, an inferior result was reported by Thapaliva et al. (2017) that found a MRSA prevalence of 3.4\% (10/293) in pork sausages within 293 samples analyzed in this product in the United States. Regardless the prevalence, the presence of MRSA in food is considered as threat to human health.

An additional fact to the possibility of the manipulators being MRSA carriers and act as sources of contamination in the abattoir flowchart is that pigs are considered as MRSA reservoirs (Oppliger, et al., 2012) and, once they are slaughtered, the contamination of carcasses and other products could occur, including cross-contamination (Kluytmans, 2010).

As for the presence of genes that code staphylococcal enterotoxins (SE), 54\% (12/22) had only gene sed, that codes the enterotoxin D and 32\% (7/22) had genes sec and sed. All isolates that tested positive to gene sec were also positive to gene sed. Moreover, all samples that had CoPS counts higher than the limit permitted by the Brazilian legislation carried S. aureus positive to the gene that coded the staphylococcal enterotoxin D. The presence of genes sea and seb was not observed.

Of the 16 MRSA isolates, $87 \%$ (14/16) had genes that coded enterotoxins, wherein 62\% (10/16) had only gene sed and 25\% (4/16) had both genes found in our study. Of the $12 \mathrm{~S}$. aureus isolates that had only gene sed, 83\% (10/12) were MRSA and of the seven isolates that had genes sec and sed, 57\% (4/7) were MRSA.

Studies that involve the presence of genes that code SE in sausages report the presence of distinct genes or gene combinations in the isolates studied. El-Maghraby et al. (2018) reported the presence of $S$. aureus isolated from sausages that could potentially produce sea, seb, sec and sed. Shylaja et al. (2018) and Sankomkai et al. (2020) noted the presence of $S$. aureus isolates from mixed-meat sausages and fermented pork sausages, respectively, with genes sea and seb and without genes sec and sed, differently from our results. The staphylococcal enterotoxins $\mathrm{C}$ and $\mathrm{D}$ were already detected in several cases of staphylococcal food poisoning that involved different foods (Carmo, et al., 2002; Goulart, et al., 2016; Denayer, et al., 2017; Schmid, et al., 2009), evidencing the importance that these enterotoxins have in public health.

The presence of genes that code SE does not necessarily indicate that the microorganism will produce the toxin in the food. However, if the enterotoxigenic strains find favorable conditions to produce enterotoxins, these toxinis will be produced in the food offering risks to public health. In our study, we found a high prevalence of enterotoxigenic S. aureus isolated from pork sausage, which indicates that this product could represent a vector of staphylococcal intoxication.

In our study, $87 \%$ of MRSA strains were potentially enterotoxigenic. A similar percentage was obtained by Savariraj 
et al. (2019) in which 94.3\% (66/70) of MRSA isolates from pork sausages had at least one gene coding an enterotoxin, with genes sea, seb, sec and sed being reported in the studied samples, differently of what we found in our study in which we observed only the genes sec and sed. The assessment of enterotoxigenic genes in MRSA isolates have been studied (Song, et al., 2016; Marques, 2017; Carfora, et al., 2015); however, the isolates generally proceed from milk and dairy products, and are rare in meat products, especially in pork sausages.

The high prevalence of MRSA and the presence of enterotoxigenic S. aureus observed in this study serve as a warning sign to public health on the necessity of adoption of control measures in food production chain to reduce the contamination of products with these microorganisms, thus decreasing the risk of transmission to people.

Of the 22 S. aureus isolates obtained, 68\% (15/22) were considered as biofilm formers by CRA test. Of these, 53\% (8/15) were MRSA and potentially enterotoxigenic (they had genes sed or sec+sed), 40\% (6/15) were MRSA and had only gene sed, $13 \%$ (2/15) were not MRSA and simultaneously had genes sec and sed and 7\% (1/15) were not MRSA and none of the genes surveyed were present.

Other studies assessed the biofilm formation by S. aureus isolated from food, except for pork sausage, which demonstrates that, although pork is highly consumed, more studies concerning this product are necessary. In a study conducted by Zhang et al. (2018), 130 S. aureus isolates from pig farms, abattoirs and ready-to-eat pork products were assessed and all of them were capable of forming biofilm, which is a higher prevalence than the prevalence found herein. Chen et al. (2020) also reported a higher prevalence, $72 \%$ (70/97) of S. aureus isolates of different foods, including fresh meat, were able to form biofilm.

Most of the biofilm forming isolates were classified as MRSA, 67\% (10/15). Khan et al. (2011) also observed that MRSA isolates tested were more likely to form biofilm than Methicillin-sensitive Staphylococcus aureus (MSSA). However, other studies reported that there were no significant differences in biofilm formation between MRSA and MSSA isolates (Reiter, et al., 2011, Smith, et al., 2008).

After being submitted to sublethal stresses, S. aureus strains responded in distinct manners, as observed in Table 1 . Most of the biofilm former isolates, $80 \%$ (12/15), continued to form a biofilm even after the application of stress. One of the biofilm former isolates did not form the biofilm in acid medium and another one, after heat stress and acid environment. Only one of the biofilm form isolates did not show this capacity after being exposed to the sublethal stresses. With respect to the non-biofilm former isolates, after undergoing the stress, two remained unchanged. However, 57\% (4/7) of non-biofilm former isolates formed biofilms after undergoing all stress challenges and one non-biofilm former isolate formed biofilm after cold stress. 
Table 1. Capacity of biofilm formation by S. aureus isolates after being submitted to different types of sublethal stress.

\begin{tabular}{|c|c|c|c|}
\hline Isolates & Heat & Cold & Acid \\
\hline \multicolumn{4}{|c|}{ Biofilm formers } \\
\hline 1 & + & + & + \\
\hline 2 & - & + & - \\
\hline 3 & + & + & - \\
\hline 4 & + & + & + \\
\hline 5 & + & + & + \\
\hline 6 & + & + & + \\
\hline 7 & + & + & + \\
\hline 8 & + & + & + \\
\hline 9 & + & + & + \\
\hline 10 & + & + & + \\
\hline 11 & + & + & + \\
\hline 12 & + & + & + \\
\hline 13 & + & + & + \\
\hline 14 & + & + & + \\
\hline 15 & - & - & - \\
\hline \multicolumn{4}{|c|}{ Non-biofilm formers } \\
\hline 16 & - & + & - \\
\hline 17 & + & + & + \\
\hline 18 & + & + & + \\
\hline 19 & - & - & - \\
\hline 20 & - & - & - \\
\hline 21 & + & + & + \\
\hline 22 & + & + & + \\
\hline
\end{tabular}

(+) biofilm formation; (-) non biofilm formation. Source: Authors.

The fact that most of the non-biofilm former isolates formed biofilm after undergoing at least one of the stress condition indicates that the stress condition induce the biofilm formation by S. aureus. According to Jefferson (2004), the reason behind the biofilm formation is a defense strategy against stress condition.

The sublethal stress condition that most induced biofilm formation by the isolates used in this study was the cold. This study is of significant importance for the food industry, since the temperature of $4 \mathrm{oC}$ is the recommended for storing pork sausages up to consumption time and, moreover, before the stuffing process there is a critical step which is a resting period of 24 hours at $4 \mathrm{oC}$ to avoid microorganism multiplication in the product (Ordóñez, et al., 2005). Likewise, sausages are generally stored under refrigeration in retail business, restaurants and households, where sometime they are manipulated in a careless manner, what could induce the capacity of $S$. aureus in forming biofilms when present in the food.

In our study, as previously reported, two out of the seven non-biofilm former isolates (29\%) remained as non-biofilm formers, a percentage that is similar as reported by Silva (2019) who tested six S. aureus isolates, three isolates were biofilm formers and the other three were non-biofilm formers, and were submitted to cold shock, heat shock and acid environment. This author reported that all biofilm former isolates remained biofilm formers after stresses and the non-biofilm former isolates, just as in our study, reacted in a distinct manner when facing stressor stimuli, despite one of the isolates $(1 / 3,33 \%)$ 
that did not form biofilm under none of the stressors tested.

Of the non-biofilm former strains studied herein, 57\% (4/7) began forming biofilm after being submitted to heat stress. Thus, heat stress could be considered as a factor that influences biofilm formation. However, Rode et al. (2007) observed that biofilm formation by $S$. aureus after being exposed to heat was low.

The results obtained in the present study, like other studies that assessed the effect of sublethal stress on biofilm formation performed with different microorganisms (Rosa, et al., 2017; Galvão, et al., 2012; Lianou \& Koutsoumanis, 2012), demonstrated that each microorganism, just as each strain of the same microorganism, has its own peculiarities when facing hostile environments, and may or may not form a biofilm.

Of the 15 biofilm former isolates in CRA, seven were selected to assess biofilm formation in stainless steel, glass, polyethylene and pork casing, with two of them being MRSA with genes sec and sed, three MRSA with only gene sed, one non-enterotoxigenic MRSA and one MSSA with genes sec and sed.

The analysis of variance of counts in each surface demonstrated that there was no effect of repetitions. According to Tukey's test, there was biofilm formation in stainless steel and pork casing in $71 \%(5 / 7)$ and $57 \%(4 / 7)$ of the isolates, respectively. The production of biofilm in glass and polyethylene was not observed (Table 2).

Table 2. S. aureus counts in different surfaces $\left(\log / 4 \mathrm{~cm}^{2}\right)$ and assessment of biofilm formation.

\begin{tabular}{|c|c|c|c|c|}
\hline Isolates & Stainless steel (SD) & Glass (SD) & Polyethilene (SD) & Pork Casing (SD) \\
\hline \multicolumn{5}{|c|}{ MRSA+sectsed } \\
\hline A & $6.2(0.8)[+]$ & $5.9(1.3)[-]$ & $5.4(1.15)[-]$ & $4.3(0.6)[-]$ \\
\hline B & $5.5(0.3)[-]$ & $5.1(1.1)[-]$ & $6.4(0.60)[-]$ & $6.0(0.6)[-]$ \\
\hline \multicolumn{5}{|l|}{ MRSA+sed } \\
\hline $\mathrm{C}$ & $5.9(0.4)[+]$ & $6.1(0.4)[-]$ & $4.6(0.49)[-]$ & $6.9(0.7)[+]$ \\
\hline $\mathrm{D}$ & $6.5(0.1)[+]$ & $6.9(0.4)[-]$ & $6.5(1.75)[-]$ & $6.9(0.0)[+]$ \\
\hline E & $5.8(1.5)[+]$ & $5.9(0.9)[-]$ & $5.5(0.24)[-]$ & $6.7(0.8)[+]$ \\
\hline \multicolumn{5}{|l|}{ MRSA } \\
\hline $\mathrm{F}$ & $5.6(0.4)[-]$ & $5.5(0.4)[-]$ & $4.8(0.22)[-]$ & $7.1(0.3)[+]$ \\
\hline \multicolumn{5}{|l|}{$\mathrm{MSSA}+\mathrm{sec}+\mathrm{sed}$} \\
\hline $\mathrm{G}$ & $7.0(0.5)[+]$ & $6.8(0.7)[-]$ & $5.8(1.17)[-]$ & $4.9(0.3)[-]$ \\
\hline Negative Control & $3.7(1.0)$ & $5.0(1.1)$ & $3.9(0.9)$ & $4.9(0.7)$ \\
\hline
\end{tabular}

$\mathrm{SD}=$ standard deviation; [+] biofilm formation; [-] non biofilm formation. Source: Authors.

None of the isolates in which we tested other abiotic surfaces other than stainless steel formed biofilm. Biofilm formation in the surface of this material was also observed by other authors that studied S. aureus isolated from different foods (Di Ciccio, et al, 2014; Lee, et al., 2015; Friedriczewski, et al., 2018). Differently from our results, some studies observed the formation of biofilm by S. aureus in glass and/or polyethylene (Lee et al. 2015, Friedriczewski, et al., 2018). The difference in the capacity of forming biofilm in glass could be related to the strains and/or food traits from which they were isolated. The ability of $S$. aureus isolates tested to form biofilm and attach to stainless steel is of great concern for food industry, since this material is commonly present in equipment and utensils within the industries and, once there is biofilm formation, it could turn 
into a constant source of contamination to food that they contact with.

This is the first study that reported the capacity of S. aureus of producing biofilm in pork casing, which is a relevant finding. Once the biofilm is present in this material, other food, equipment, and surfaces could be contaminated when they contact, in addition to represent a direct risk for people that consume them. According to Iñiguez-Moreno et al. (2018), the multiplication of microorganisms in food surfaces is one of the main causes of deterioration and loss in processed and fresh products, and is also one of the main causes of foodborne illnesses and damage to equipment in food industry. Furthermore, since all biofilm formers that we isolated in pork casing were MRSA positive, they represent a huge risk and become very relevant to public health.

The presence of genes sec and sed, the methicillin resistance or the combination of both factors in the isolates studied are pathogenic mechanisms that, in addition to the capacity of forming a biofilm, turn the occurrence of S. aureus in sausages a bigger issue when it comes to food safety to consumers.

\section{Conclusion}

Methicillin-resistant $S$. aureus and the potential staphylococcal producers of enterotoxins $\mathrm{C}$ and D can be isolated from fresh pork sausages and were capable of forming biofilm, including in surfaces such as stainless steel and pork casing. Some $S$. aureus strains non-biofilm formers, when submitted to determined stress conditions, such as refrigeration, develop the capacity of forming biofilm.

These results highlight the importance of the implementation of good manufacturing practices within the industry to control microbial contamination and biofilm formation.

\section{References}

Andretta, M. (2019). Serro artisanal cheese produced in Brazil has a microbial safety status for consumers. https://www.locus.ufv.br/bitstream/handle/123456789/25766/texto\%20completo.pdf?sequence=1\&isAllowed=y

Bauer, A. W., Kirby, W. M., Sherris, J. C. \& Turch, M. (1966), Antibiotic susceptibility testing by a standardized single 457 disk method. American Journal of Clinical Pathology, 45 (4), 493-496.

Botelho, C. V. (2017). Staphylococcus coagulase positiva e Staphylococcus aureus resistentes a antibióticos em cadeia produtiva de carne suína. https://www.locus.ufv.br/bitstream/handle/123456789/18691/texto\%20completo.pdf?sequence=1

Brasil - Ministério da Agricultura e do Abastecimento. (2017). Decreto nº 9.013, de 29 de março de 2017. Regulamento de inspeção industrial e sanitária de produtos de origem animal. https://www.gov.br/agricultura/pt-br/assuntos/aquicultura-e-pesca/legislacao/legislacao-geral-da-pesca/decreto-no-9-013-de-2903-2017.pdf/view\#: :text=Regulamenta\%20a\%20Lei\%20n\%C2\%BA\%201.283,de\%20produtos\%20de\%20origem\%20animal

Brasil - Ministério da Agricultura e do Abastecimento. (2001). Resolução n ${ }^{\circ}$ 12, de 02 de janeiro de 2001. Regulamento técnico sobre padrões microbiológicos para alimentos. http://portal.anvisa.gov.br/documents/33880/2568070/RDC_12_2001.pdf/15ffddf6-3767-4527-bfac-740a0400829b\#: :text=1\%C2\% BA\%20Aprovar\%20o\%20REGULAMENTO\%20T\%C3\%89CNICO,1977\%2C\%20e\%20demais\%20disposi\%C3\%A7\%C3\%B5es\%20aplic\%C3\%A1veis

Carfora, V., Caprioli, A., Marri, N., Sagrafoli, D., Boselli, C., Giacinti, G., Giangolini, G., Sorbara, L., Dottarelli, S., Battisti, A. \& Amastite, S. (2015). Enterotoxin genes, enterotoxin production, and methicillin resistance in Staphylococcus aureus isolated from milk and dairy products in Central Italy. International Dairy Journal, 42, 12-15.

Carmo, L. S., Dias, R. S., Linardi, V. R., Sena, M. J., Santos, D. A., Faria, M. E., Pena, E. C., Jett, M. \& Heneine, L. G. (2002). Food poisoning due to enterotoxigenic strains of Staphylococcus present in Minas cheese and raw milk in Brazil. Food Microbiology, 19 (1), 9-14.

Chang, C. M., Chiang, M. L. \& Chou, C.C. (2004). Responses of heat-shocked Vibrio parahaemolyticus to subsequent physical and chemical stresses. Journal of Food Protect, 67 (10), 2183-2188.

Chen, Q., Xie, S., Lou, X., Cheng, S., Liu, X., Zheng, W., Zheng, Z. \& Wang, H. (2019). Biofilm formation and prevalence of adhesion genes among Staphylococcus aureus isolates from different food sources. Microbiology Open, 9 (1), 1-11.

CLSI - Clinical and Laboratory Standards Institute. (2019). Performance Standards for Antimicrobial Susceptibility Testing - Twenty Fourth Informational Supplement. https://clsi.org/media/2663/m100ed29_sample.pdf

Cunha, M. R. L. S., Calsolari, R. A. O. \& Júnior, J. P. A. (2007). Detection of Enterotoxin and Toxic Shock Syndrome Toxin 1 Genes in Staphylococcus, with Emphasis on Coagulase Negative Staphylococci. Microbiology and Immunology, 51 (4), 381-390. 
De Buyser, M. L., Dufour, B., Maire, M. \& Lafarge, V. (2001). Implication of milk and milk products in food-borne diseases in France and in different industrialised countries. International Journal of Food Microbiology, 67 (1-2), 1-17.

Denayer, S., Delbrassinne, L., Nia, Y. \& Botteldoorn, N. (2017). Food-borne outbreak investigation and molecular typing: high diversity of Staphylococcus aureus strains and importance of toxin detection. Toxins, 9 (12), 407.

Di Ciccio, P., Vergara, A., Festino, A. R., Paludi, D., Zanardi, E., Ghidini, S. \& Lanieri, A. (2015). Biofilm formation by Staphylococcus aureus on food contact surfaces: Relationship with temperature and cell surface hydrophobicity. Food Control, 50, 930-936.

Donlan, R. M. \& Costerton, J. M. (2002). Biofilms: survival mechanisms of clinically relevant microorganisms. Clinical Microbiology Reviews, 15 (2), $167-$ 193.

El-Maghraby, M. S., Hassan, M. A., Hassanin, F. S. \& Shawky, N. A. (2018). Detection of Enterotoxigenic Staphylococcus aureus in Meat Product Sandwiches Using Multiplex PCR. Benha Veterinary Medical Journal, 35 (1), 190-196.

Franco, B. D. G. M. \& Landgraf, M. (2008), Microbiologia dos Alimentos. Atheneu.

Freeman, D. J., Falkiner, F. R. \& Keane, C. T. (1989). New method for detecting slime production by coagulase-negative staphylococci. Journal Clinical Pathology, 42 (8), 872-874.

Friedriczewski, A. B., Gandra, E. Á., Da Conceição, R. C., Cereser, N. D., Moreira, L. M. \& Timm, C.D. (2018). Biofilm Formation by Coagulase-Positive Staphylococcus aureus Isolated from Mozzarella Cheese Elaborated with Buffalo Milk and its Effect on Sensitivity to Sanitizers. Acta Scientiae Veterinariae, $46(1), 6$.

Galvão, N. N., Chiarini, E., Destro, M. T., Ferreira, M. A. \& Nero, L. A. (2012). PFGE characterisation and adhesion ability of Listeria monocytogenes isolates obtained from bovine carcasses and beef processing facilities. Meat science, 92 (4), 635-643.

Germano, P. M. L., \& Germano, M. I. S. (2015). Higiene e vigilância sanitária de alimentos. Manole.

Giaouris, E., Heir, E., Hébraud, M., Chorianopoulos, N., Langsrud, S., Moretro, T., Habimana, O., Desvaux, M., Renier, S. \& Nychas, G. J. (2014). Attachment and biofilm formation by foodborne bacteria in meat processing environments: causes, implications, role of bacterial interactions and control by alternative novel methods. Meat Science, 97 (3), 298-309.

Goulart, A. R., Lacerda, I. C. A. \& Dias, R. S. (2016). Potencial risco de intoxicação alimentar por Staphylococcus spp. enterotoxigênicos isolados de bolos com cobertura e recheio. NBC Periódico Científico do Núcleo de Biociências, 6 (11), 11-17.

Haaber, J., Cohn, M. T., Frees, D., Andersen, T. J. \& Ingmer, H. (2012). Planktonic aggregates of Staphylococcus aureus protect against common antibiotics. Plos One, 7 (7).

Iñiguez-Moreno, M., Gutiérrez-Lomelí, M., Guerrero-Medina, P. J. \& Avila-Novoa, M. G. (2018). Biofilm formation by Staphylococcus aureus and Salmonella spp. under mono and dual-species conditions and their sensitivity to cetrimonium bromide, peracetic acid and sodium hypochlorite. Brazilian Journal Microbiology, 49 (2), 310-319.

Jefferson, K. K. (2004). What drives bacteria to produce a biofilm? FEMS Microbiology Letters, 236 (2), 163-173.

Khan, F., Shukla, I., Rizvi, M., Mansoor, T. \& Scharma, S. C. (2011). Detection of biofilm formation in Staphylococcus aureus. Does it have a role in treatment of MRSA infections. Trends in Medical Research, 6 (2), 116-123.

Kluytmans, J. A. J. W. (2010). Methicillin-resistant Staphylococcus aureus in food products: cause for concern or case for complacency? Clinical Microbiology and infection, 16 (1), 11-15.

Lee, A., De Lencastre, H., Garau, J., Kluytmans, J., Malhotra-Kumar, S., Peschel, A. \& Harbarth, S. (2018). Methicillin-resistant Staphylococcus aureus. Nature Reviews Disease Primers, 4 (1), 1-23.

Lee, J. S., Bae, Y. M., Lee, S. \& Lee, S. Y. (2015). Biofilm formation of Staphylococcus aureus on various surfaces and their resistance to chlorine sanitizer", Journal of food science, 80 (10), 2279- 2286.

Lianou, A. \& Koutsoumanis, K. P. (2012). Strain variability of the biofilm-forming ability of Salmonella enterica under various environmental conditions International Journal of food microbiology, 160 (2), 171-178.

Linhares, L. L., Yang, M., Sreevatsan, S., Munoz-Zanzi, C. A., Torremorell, M. \& Davies, P. R. (2015). The effect of anatomic site and age on detection of Staphylococcus aureus in pigs. Journal of Veterinary Diagnostic Investigation, 27 (1), 55-60.

Lowy, F. D. (1998). Staphylococcus aureus infections. The New England Journal of Medicine, 339 (8), 520-532.

Marques, L. M. P. (2017). Caracterização fenotípica e genotípica de Staphylococcus aureus isolados de queijo minas frescal" https://app.uff.br/riuff/bitstream/1/3305/1/Marques\%2c\%20Leila\%20M\%c3\%a1rcia\%20Peres\%20\%5bDisserta\%c3\%a7\%c3\%a3o\%2c\%202014\%5d.pdf

Milan, C., Agostinetto, A., Conceição, R. C. S., Gonzalez, H. L. \& Timm, C.D. (2015). Sanitizer resistance of biofilm-forming Salmonella isolated from meat products. Arquivo Brasileiro de Medicina Veterinária e Zootecnia, 67 (2), 642-646.

Oppliger, A., Moreillon, P., Charrière, N., Giddey, M., Morisset, D. \& Sakwinska, O. (2012). Antimicrobial resistance of Staphylococcus aureus strains acquired by pig farmers from pigs. Applied and Environmental Microbiology, 78 (22), 8010-8014.

Ordóñez, J. A. (2005). Tecnologia de alimentos: Alimentos de Origem Animal. ArtMed. 
Reiter, K. C., Da Silva, T. G., De Oliveira, C. F. \& D’Azevedo, P. A. (2011). High biofilm production by invasive multiresistant staphylococci. Apmis, 119 (11), 776-781.

Robert, S. \& Chambers, S. (2005). Diagnosis and management of Staphylococcus aureus infections of the skin and soft tissue. Internal Medicine Journal, 35, $97-105$.

Rode, M. T., Langsrud, S., Holck, A. \& Moretro, T. (2007). Different patterns of biofilm formation in Staphylococcus aureus under food-related stress conditions. International Journal of Food Microbiology, 116 (3), 372-383.

Rosa, J. V., Kaefer, K., Da Conceição, N. V. D., Da Conceição, R. C. S. \& Timm, C. D. (2017). Formação de biofilme por Vibrio parahaemolyticus isolados de pescados. Pesquisa Veterinária Brasileira, 37 (4), 339-345.

Sambrook, J. \& Russel, D. W. (2001). Molecular Cloning: A Laboratory Manual. Cold Spring Harbor Laboratory Press.

Sankomkai, W., Boonyanugomol, W., Kraisriwattana, K., Nutchanon, J., Boonsam, K., Kaewbutra, S. \& Wongboot, W. (2020). Characterisation of classical enterotoxins, virulence activity, and antibiotic susceptibility of Staphylococcus aureus isolated from Thai fermented pork sausages, clinical samples, and healthy carriers in northeastern Thailand. Journal of Veterinary Research, 64 (2), 289-297.

Santa, O. R. D., Alvarez, D. C., Santa, H. S. D., Zanette, C. M., De Freitas, R. J. S., De Macedo, R. E. F. \& Terra, N. N. (2012). Microbiota of sausages obtained by spontaneous fermentation produced in the South of Brazil. Ciência e Tecnologia de Alimentos, 32 (4), 653-660.

Sasaki, T., Tsubakishita, S., Tanaka, Y., Sakusabe, A., Ohtsuka, M., Hirotaki, S., Kawakami, T., Fukata, T. \& Hiramatsu, K. (2010). Multiplex-PCR method for species identification of coagulase-positive staphylococci. Journal of Clinical Microbiology, 48 (3), 765-769.

Savariraj, W. R., Ravindran, N. B., Kannan, P., Paramasivam, R., Senthilkumar, T. M. A., Kumarasamy, P. \& Rao, V. A. (2019). Prevalence, antimicrobial susceptibility and virulence genes of Staphylococcus aureus isolated from pork meat in retail outlets in India. Journal of food safety, 39 (1).

Schmid, D., Fretz, R., Winter, P., Mann, M., Höger, G., Stöger, A., Ruppitsch, W., Ladstätter, J., Mayer, N., De Martin, A. \& Allerberger, F. (2009). Outbreak of staphylococcal food intoxication after consumption of pasteurized milk products, June 2007, Austria. Wiener Klinische Wochenschrift, 121 (3-4), 125-131.

Shylaja, M., Goud, S. S. S., Samatha, K. \& Pradeep, C. H. (2018). Studies on the incidence of Staphylococcus aureus and its enterotoxins in different meat and meat products. The Pharma Journal, 7 (4), 669-673.

Silva, J.R. (2019). Caracterização fenotípica de Staphylococcus aureus isolados de alimentos de origem animal e de outras fontes relacionadas. https://wp.ufpel.edu.br/ppgveterinaria/files/2019/09/Julia-Rosin-da-Silva.pdf

Smith, K., Perez, A., Ramage, G., Lapin, D., Gemmell, C. G. \& Lang, S. (2008). Biofilm formation by Scottish clinical isolates of Staphylococcus aureus. Journal of Medical Microbiology, 57 (8), 1018-1023.

Song, J. W., Yang, S. J., Shin, S., Seo, K. S., Park, Y. H. \& Park, K. T. (2016). Genotypic and phenotypic characterization of methicillin-resistant Staphylococcus aureus isolated from bovine mastitic milk in Korea. Journal of food protection, 79 (10), 1725-1732.

Strube, M. L., Hansen, J. E., Rasmussen, S. \& Pedersen, K. (2018). A detailed investigation of the porcine skin and nose microbiome using universal and Staphylococcus specific primers. Scientific Reports, 8 (1), 1-9.

Tallent, S., Hait, J., Bennett, R. W. \& Lancette, G. A. (2016). Staphylococcus aureus. In: U.S. Food and Drug Administration, Bacteriological analytical manual, chap. 12. https://www.fda.gov/food/laboratory-methods-food/bam-chapter-12-staphylococcus-aureus

Thapaliya, D., Forshey, B. M., Kadariya, J., Quick, M. G., Farina, S., O’Brien, A., Nair, R., Nworie, A., Hanson, B., Kates, A., Wardyn, S. \& Smith, T. C. (2017). Prevalence and molecular characterization of Staphylococcus aureus in commercially available meat over a one-year period in Iowa, USA. Food microbiology, 65, 122-129.

Tutenel, A. V., Pierad, D., Hoff, J. V., Cornelis, M. \& Zutter, L. D. (2003). Isolation and molecular characterization of Escherichia coli O157 isolated from cattle pigs and chickens at slaughter. International Journal of Food Microbiology, 84 (1), 63-69.

USDA - United States Department of Agriculture. (2019). Livestock and Poultry: World Markets and Trade. https://downloads.usda.library.cornell.edu/usdaesmis/files/73666448x/g445ct12h/ff365k146/Livestock_poultry.pdf

Valiatti, T. B., Barcelos, I. B., Calegari, G. M., Silva, W. M. C., Almeida, F. K. V., Dos Prazeres, P. F. L., Sobral, F. O. S., Romão, N. F. \& Gasparotto, P. H. G. (2016). Avaliação microbiológica de linguiças tipo frescal comercializadas em supermercados do município de Ji-Paraná, Rondônia. Revista da Universidade do Vale do Rio Verde, 14 (2), 678-686.

Wong, H. C., Peng, P. Y., Han, J. M., Chang, C. Y. \& Lan, S. L. (1998). Effect of mild acid treatment on the survival, enteropathogenicity, and protein production in Vibrio parahaemolyticus. Infection and Immunity, 66 (7), 3066-3071.

Zhang, Y., Xu, D., Shi, L., Cai, R., Li, C. \& Yan, C. (2018). Association between agr type, virulence factors, biofilm formation and antibiotic resistance of Staphylococcus aureus isolates from pork production. Frontiers in microbiology, 9, 1876. 